\title{
The Effect of Principal Leadership, Teacher Performance and Learning Facilities on Student Achievement in SMPN 1 Kepanjen Malang, Indonesia
}

\author{
Marselinus Reo Due ${ }^{1}$, Fajar Supanto ${ }^{2}$, Rudy Wahyono ${ }^{3}$ \\ ${ }^{1}$ Master Management Program, University of Merdeka Malang, Indonesia \\ ${ }^{2,3}$ University of Merdeka Malang, Indonesia
}

\begin{abstract}
The purpose of this study was to determine the effect of school principal leadership, teacher performance and learning facilities on student achievement in SMP Negeri 1 Kepanjen. The design of this research is causality design with a quantitative approach. The population and sample in this study were all teachers of SMP Negeri 1 Kepanjen, amounting to 50 people with the data collection techniques in the form of questionnaires and documentation of data. The technique of data analysis used in this study is multiple linear regression analysis techniques. The results of this study indicate that learning facilities have no effect on student achievement, leadership and teaching performance. Headmaster Significantly influences student achievement, and teacher performance has a dominant influence on student achievement.
\end{abstract}

Keywords: Student Learning Achievement, Leadership Principal, Teacher Performance, Learning Facilities.

\section{INTRODUCTION}

Schools as formal educational institutions to work to prepare human resources is one important component in the development in all fields. In carrying out his duties as a printer of human resources, the school is required to fulfill the wishes and expectations of society. To meet the expectations and desires msyarakat increases, then the school as an educational organization should attempt to assess the various advantages and disadvantages to seek to continuous improvement and to identify the challenges and threats to improve student achievement.

Schools with professional leaders and supported by teachers who have high performance as well as a comprehensive learning facility is expected to produce achievement as expected. Should have the commitment and good performance on the job. That is, teachers must have awareness of and love for the profession. With the awareness and passion for her work as a teacher, motivation, performance and awareness to develop her potential will increase. In an effort to raise awareness of the importance of teachers' professional competence and increase the quality of work, the principals as leaders of educational institutions play an important role to always provide motivation,

The headmaster plays an important role in providing education in the school with responsibility for management of the wheels fully to the rules of education in schools. The main role of the principal is a leader who control the course of the organization of education in which he is assigned. In view Supriadi, a close relation between the quality of principals with various aspects of school life such as school discipline, school culture, and the decline in unruly behavior of learners [1].

What is described above is becoming more important in line increasing complexity of the task demands of school heads, favoring work demands more effectively and efficiently. Realizing this, every school principal faced with the challenge to implement educational development in a focused, planned and sustainable to improve the quality of education. Within this framework the perceived need for increased performance in professional principals to succeed in one of the government program, which program to improve the quality of learning. In accordance with the conditions set by the Ministry of National Education, the main duties of a school principal is as educators, managers, administrators, supervisors, leadership [2]

SMP Negeri 1 Kepanjen is one of the oldest schools in the city Kepanjen. SMP Negeri 1 Kepanjen also one of the public schools most in interest by students / $\mathrm{i}$ in town Kepanjen, can be seen from the number of students / $\mathrm{i}$ who attend school there, which reached 1041 students. With most public schools in the interest of the students, of course SMP Negeri 1 Kepanjen have a myriad of achievements both in academic and non-academic. Student achievement in SMP Negeri 1 Kepanjen been good, but there are still some students who have not completed. It is of course likely to be influenced by the leadership of the principal, teacher performance and student learning facility that is still less than optimal, causing still students who did not complete. 
Teachers is one of the important human resources and influence on the quality of education. Master is a person who has a dominant influence and most importantly in the formal education in general. Awareness of teachers to increase kinerjannya must be based on a strong commitment to the school as an organization for which they work and apply their knowledge. Commitment of teachers is in need for the continuation of the school as an educational organization. One effort to create a strong commitment to the organization how the principal as leader mengkondinisikan teachers and other education personnel to work and perform their duties with full responsibility. The lack of commitment of teachers inflicting damage not only to the teacher as an individual, but also to the students as an educational service users.

another factorthat affect student achievement is learning facilities. The quality of education that was developed in order to remain well, we need to hold the facilities that can help and encourage student achievement.

According Bafadal, study facilities can be grouped into (1) learning tool is all the equipment, materials, and furnishings that are directly used in the learning process. While (2) learning infrastructure are all basic accessory device that does not directly support the implementation of the learning process [3]. "Facilities are facilities and infrastructure required to perform or facilitate an activity" [4]. The learning facilities in very important to improve the skills of managing, if not learning facilities in accordance with the operational standards that will affect student achievement.

Based on some of the above opinion by not ignoring other factors, the teacher is considered as decisive factors to the increase and decrease in the quality of education. Therefore how pentingnnya coaching teacher directed and programmed to enhance the ability and passion of teaching, so as to improve student achievement. But this is inseparable from the performance of teachers themselves, learning resources and how the school leadership is well run. The teacher's performance is influenced by several factors, among others ideals or aspirations, ability of teachers, individuals or environmental conditions, as well as the efforts undertaken coaching principals.

The purpose of this study was to determine the effect of school leadership, teacher performance and learning facilities on student achievement SMP Negeri 1 Kepanjen.

\section{LITERATURE}

\subsection{Student achievement}

Slameto, defines that learning is a process attempts person to obtain a new behavior changes as a whole, as a result of his own experience in the interaction with the environment [5]. Tirtonegoro, also defines the achievement of business outcomes assessment in learning activities stated in the form of symbols or numbers, letters or words that can reflect the results already achieved by each student in a particular period [6]. So student achievement is the results that have been achieved by the students of the teaching and learning process which has been passed by the student in a particular period.

So learning achievement is the real capacity that results from interactions between the various factors that affect both from within and from outside the individual in the study.

\subsection{Leadership Principal}

Thoha says bahwwa "leadership (leadership) is a relationship between a person with another person, the leader is able to influence others to be willing to work together on tasks related to achieving the desired goal" [7]. While Mulyasa defines "kepemimpina as the art of persuading subordinates to want to do the tasks with confidence and spirit" [8].

According Wahjosumidjo "leadership is an important force in the management, therefore ability to lead effectively is the key to the success of the organization" [9]. While the leadership expressed by Reksoprodjo Handoko, says that "leadership (leadership) is a relationship between a person with another person, a leader capable mempengarhi other people that are willing to work together on tasks related to achieving the desired goal" [10]. Sujak, argues that "leadership is a pattern relationship between individuals who exercise authority and influence over another person or group of people in order to form collaboration to complete a task" [11].

\subsection{Teacher Performance}

Performanceis the result of the quality and quantity of work that can be accomplished by an employee in performing its duties in accordance with the responsibilities given to him. Definition of performance by Kusriyanto. is a comparison of the results achieved with the participation of labor per unit of time (usually an hour). Gomes in Mangkunegara, suggests the definition of performance as an expression such as output, efficiency and effectiveness is often associated with productivity [11]. Meanwhile, According to Mangkunegara, employee performance (performance) is the result of the quality and quantity of work achieved by an employee in performing their duties in accordance with the responsibilities given to him [11]. Therefore it can be concluded that the performance of HR is job performance, or work (output) of both quality and quantity of human resources achievable per unit time period in performing its duties in accordance with the responsibilities given to him. Performance appraisal is led effort to assess the work of subordinates. According Mengginson in Mangkunegara, performance appraisals (performance appraisal) is a process used to determine whether the leadership of an employee performs work in accordance with 
the duties and responsibilities. Furthermore Sikula in Mangkunegara, argues that employee assessment is a systematic evaluation of employee jobs and the potential that can be developed. Assessment in the process of interpretation or determination of value, quality or status of some object or a person for something [11]. According to Handoko, performance appraisals (performance appraisal) is the process through which organizations evaluate or assess employee performance. This activity can improve personnel decisions and provide feedback to employees about their operations [12].

\subsection{Concept Learning Facilities}

According Daryanto, etymologically the word facilities which consist of facilities and infrastructure, that means learning is a direct tool to achieve educational goals, such as the location of places, buildings and others, while infrastructure is a tool that is not directly to achieving educational goals, such as space, books, libraries, laboratories and so on [13]. Utilization of facilities effective and efficient learning can enhance learners' active role in the learning process. Usually the active role of learners is because learners interested and interests with ongoing learning materials. According Djamarah et al, with the stimulation of learning, students are not difficult to achieve teaching objectives. Because non-teaching that forced students to achieve the goal (14).

But unfortunately, often encountered students who have weaknesses in receive and understand the contents of the learning material, either because of the content of the material is hard, the way educators are less attractive and monotonous, because of personal problems, or maybe even less supportive environment. Learners who have a weakness of this study, it will usually re interested to learn if educators are sensitive to the problems of learners. If it is because the issue of content that elusive and educators are less attractive delivery and monotonous, educators need to use the facilities that are conducive to interactive learning in the classroom.

According Daryanto and Farid, Education Facility divided into three kinds when viewed from a relationship with the learning process, such as books, visual aids, stationery and teaching aids. Educators need a learning tool to support learning activities [15]. Especially to deal with students who experience a loss of learning, then this is where the creativity of educators are highly demanded. For example, educators want to show the European continent, the educator can not only explain orally, it is necessary to use visual media such as a map or a globe to show the learners so that with the use of appropriate means with instructional materials can stimulate the desire of students to learn.

Schneider says: "Reviews those Involved in school planning design see this as an opportunity to Enhance academic outcomes by creating better learning environments" (even those involved in school planning and design, sees this as an opportunity to improve academic results with creating a better environment) [16]. For educators in particular, creating conditions to learn a fun, active and innovative should be considered and planned carefully, so that the learning process more interesting and meaningful. To create a learning process interesting and meaningful not only focused on the classroom, educators can take advantage of the infrastructure available at the school.

According Daryanto and Farid of educational facilities in schools can be classified into two types, namely: 1) infrastructure of education is directly used for teaching and learning, such as: classrooms, library, practice skills, and laboratory space. 2) infrastructure of schools whose existence is not directly used for teaching and learning, but are directly supporting the teaching and learning processes, such as: office space, rooms, school canteen, the ground and the way to school, a small room, the room school health, space educator, the principal's office, and vehicle parking [15].

\subsection{Hypothesis}

The research hypotheses as follows:

1) Allegedly principal leadership, teacher performance and learning facilities simultaneously significant effect on student achievement at SMP Negeri 1 Kepanjen.

2) Allegedly principal leadership, teacher performance and learning facilities partially significant effect on student achievement at SMP Negeri 1 Kepanjen

3) Anticipated performance of teachers have a dominant influence on student achievement at SMP Negeri 1 Kepanjen.

\section{METHODOLOGY}

\subsection{Operational Definition of Variables}

1) School leadership (X1) that is the ability of the principal to persuade others to cooperate in accordance with the plan to achieve the goals set. Indicators of school leadership in this research compiled include: realizing an effective learning process, creating a safe school environment, cultivate the power quality in schools, fostering expectations of high achievement, implementing effective management of educational personnel and implement effective management of learning resources.

2) The performance of teachers (X2) is the appearance of the work done by teachers in performing their duties and responsibilities to provide tutoring that provides knowledge and skills that will lead to improvements in learners' 
achievements. Indicators on teacher performance assessment conducted on three learning activities in the classroom: planning program of learning activities, the implementation of learning activities, and evaluation / assessment of learning.

3) Learning facilities (X3) is an infrastructure that helps simplify the process of learning to acquire knowledge in school in order to reach the learning objectives. The indicators studied in this research facility arranged include: teaching tools, props, media, schools and libraries.

4) The learning achievement (Y) is the result of the measurement of learners that includes factors of cognitive, affective and psychomotor after following the learning process as measured using the relevant test instruments. As for the indicators of learning achievement include observation, memory, comprehension, application, analysis (inspection and sorting carefully) and synthesis (create new guidelines and intact).

\subsection{Population and Sampling Techniques}

According to Sanusi, the population is the entire collection of elements that show certain characteristics that can be used to make inferences [17]. The population in this study were teachersSMP Negeri 1 Kepanjen totaling 50 people,

According Arikunto samples is how researchers took a sample or a representative sample of the population that are available [18]. According Arikunto, "One sample can technically be seen as a large sample if $\mathrm{N} \geq 30$, it means the sample is already eligible normality in a study" [19]. Engineering samples used in this study using saturated sampling. According Sugiyono saturated sampling is sampling technique when all members of the population used as a sample [20]. This is often done when the population size is relatively small, less than 100 people. Another term saturated sample census, where all members of the population sampled. In this research is the study of the sampled teachersSMP Negeri 1 Kepanjen totaling 50 people.

\subsection{Data Analysis Techniques}

The data analysis technique used is the analysis of qualitative and quantitative analysis. In the quantitative analysis using multiple linear regression analysis techniques, whereas hypothesis testing using the F test and test. Multiple regression analysis is a statistical model used to measure the effect of two or more independent variables on the dependent variable [18].

\section{RESULTS AND DISCUSSION}

\section{1. analysis Multiple Linear Regression}

From processing results data with the help of a computer program SPSS 15 for windows obtainable the results of such analysis in the following table:

Table 1. Analysis Multiple Linear Regression

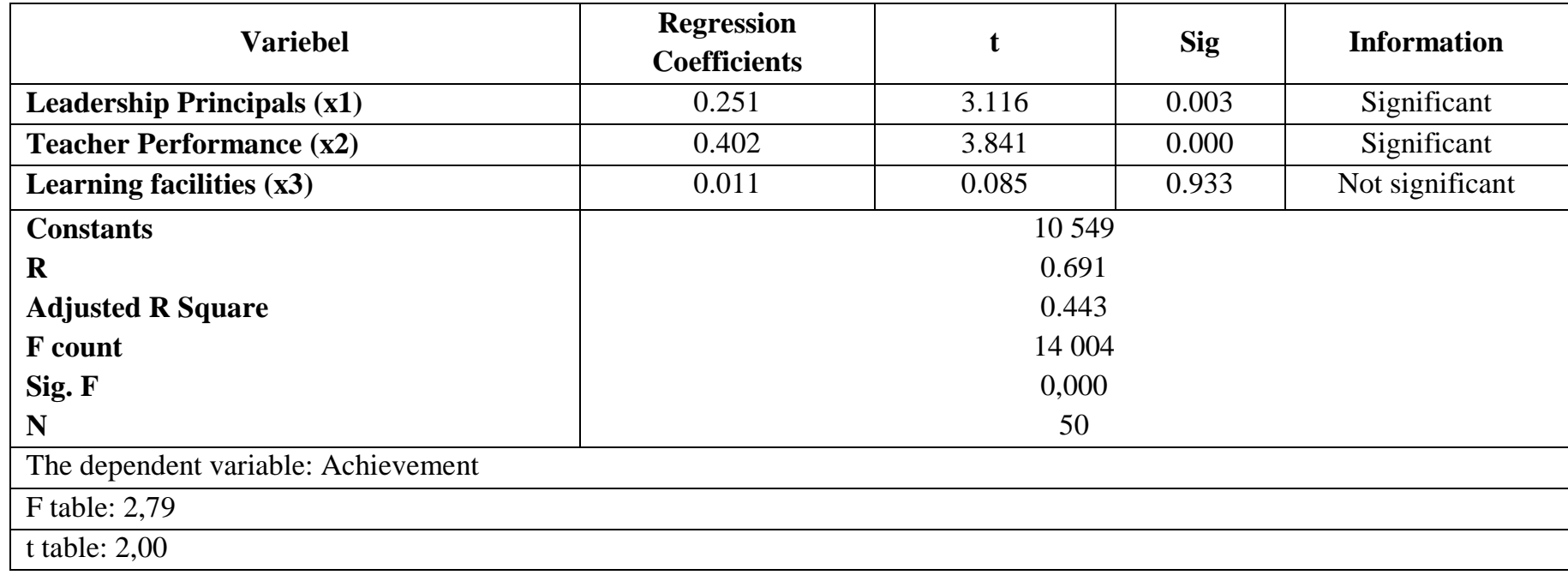

Sources: Primary data is processed in 2019

Based on the recapitulation table, obtained by multiple regression equation as follows:

Y: $10549+0.251 \times 1 \times 2+0402+0.011 \times 3$

Based on these equations can be explained as follows:

$\alpha=10549$ is a constant which means that if all the independent variables Leadership principals (x1), Teacher Performance (x2), Learning Facility (x3) is 0, then the magnitude of the variable Achievement of 10549

$\beta 1=0,251$ is the coefficient of the independent variable regeresi school leadership $(\mathrm{x} 1)$, multiple regression coefficient positive and significant value smaller than 0.5 is positive showing principal leadership variables influence the direction of the Student Achievement that is to say, the better the school leadership Student Achievement the better, assuming Teacher 
performance (x2), and Learning Facility (x3) fixed amount. While the influence of school leadership on learning achievement by 0.251 .

$\beta 2=0402$ is the independent variable regression coefficient Teacher Performance (x2), multiple regression coefficient positive and significant value less than 0.5 indicates variables influence the direction of the Teacher Performance Student Achievement Teacher Performance means teacher at SMPN 1 Kepanjen have an influence on Achievement assuming leadership of the principal variables (x1) x3 Learning facilities fixed amount. While the influence of the Teacher Performance Student Achievement by 0402.

$\beta 3=0011$ is the independent variable regression coefficient Learning Facility (x3), positive multiple regression coefficient smaller than 0.5 indicate variables influence the direction of the Facilities Study Student Achievement. That is the provision of a comprehensive learning facility will help improve learning achievement, assuming school leadership level variables (x1) and the Teacher Performance (x2), fixed amount. While the influence of the Learning Achievement Learning Facility for 0011.

The coefficient of determination (Adjusted $\mathrm{R}$ square) of 0.443 indicates this determination means that, school leadership ( 1 ) Teacher Performance (x2), and Learning Facility (x3) together to contribute to the learning achievement.

\subsection{Hypothesis testing}

\section{a. Hypothesis 1}

To test the first hypothesis which states that the alleged leadership of the principal, the performance of teachers and learning facilities simultaneously significant effect on student achievement, it will be determined by F-test using SSPS program for windows as follows:

Table 2. Results of Test $\mathbf{F}$

\begin{tabular}{|c|c|c|c|c|c|c|}
\hline \multicolumn{7}{|c|}{ ANOVA $^{b}$} \\
\hline \multicolumn{2}{|c|}{ Model } & Sum of Squares & Df & mean Square & $\mathbf{F}$ & Sig. \\
\hline \multirow[t]{3}{*}{1} & Regression & 207.510 & 3 & 69.170 & 14.004 & $0.000^{\mathrm{a}}$ \\
\hline & residual & 227.210 & 46 & 4.939 & & \\
\hline & Total & 434.720 & 49 & & & \\
\hline
\end{tabular}

Sources: Primary data is processed in 2019.

From the calculation of multiple regression analysis using SPSS acquired Fhitung= 14.004 and probability 0,000 . because the value of Fhitung greater than Ftabeland the probability is smaller than $\alpha$ 0.05, Leadership Principal (X1), Teacher Performance (X2), and Learning Facility (X3), simultaneously or overall significant effect on Student Achievement (Y). Thus, based on the calculation of the above it can be concluded that the first hypothesis is proven and tested statistically.

\section{b. Hypothesis 2}

To test the second hypothesis which states that the alleged leadership of the principal, teacher performance and learning facilities are partially significant effect on learning achievement, it will be determined by t test. The t-test is used to determine the regression coefficient (beta) of each independent variable. To determine where the dominant influence variables can be seen in the following table:

Table 3. Results of $t$ test

\begin{tabular}{|c|c|c|c|c|c|c|}
\hline & \multirow[b]{2}{*}{ Variables } & \multicolumn{2}{|c|}{ Coefficients unstandardized } & \multirow{2}{*}{$\begin{array}{c}\begin{array}{c}\text { standardized } \\
\text { Coefficients }\end{array} \\
\text { beta }\end{array}$} & \multirow[b]{2}{*}{$\mathbf{t}$} & \multirow[b]{2}{*}{ Sig. } \\
\hline & & B & Std. Error & & & \\
\hline \multirow[t]{4}{*}{1} & (Constant) & 10549 & 5643 & & 1,869 & 0.068 \\
\hline & Leadership Principal & 0.251 & 0.081 & 0.367 & 3,116 & 0.003 \\
\hline & Teacher performance & 0.402 & 0.105 & 0.462 & 3.841 & 0.000 \\
\hline & Learning facilities & 0.011 & 0.130 & 0.009 & 0.085 & 0.933 \\
\hline
\end{tabular}

Sources: Primary data is processed in 2019 
Based on the above table shows that the value of the variable $t$ significance of school leadership by $0.003 \leq \alpha=0.05$, this shows the principal's leadership is partially significant effect on student achievement. Teacher performance variable indicates the significant value of $0000 \mathrm{t} \leq \alpha=0.05$, it shows the teacher's performance is partially significant effect on student achievement. Variables learning facilities showed significant value thitung 0933 $>\alpha=0.05$, this indicates a partial learning facilities no significant effect on learning achievement.Thus the second hypothesis has not been proven statistically.

\section{c. Hypothesis 3 (Dominant Influence)}

To test the third hypothesis stating the suspect variable dominant influence teacher performance on student achievement, then the details can be measured throught test. The t-test is used to determine the regression coefficient (beta) each independent variable and the independent variables which are dominant as in table 3. Table 3 According to the table above shows that the significant value of the variable $t$ school leadership by $0.003 \leq \alpha=0.05$, this shows a significant effect of school leadership on student achievement. Teacher performance variable indicates the significant value of $0000 \mathrm{t} \leq \alpha=0.05$, demonstrating the significant effect of teacher performance on student achievement. Variables learning facilities showed significant value thitung 0933> $\alpha=0.05$, it indicates learning facilities no significant effect on student achievement. Of the three independent variables in the partial test it appears that the beta coefficient teacher performance variable is greater than the variable of school leadership and learning facilities. Thus it can be concluded that the variable dominant influence teacher performance on student achievement,

\subsection{Discussion}

\subsubsection{Principal Leadership Influence on Student Achievement}

Based on the results of research and data analysis, the result for the principal's leadership have a significant effect on student achievement SMP Negeri 1 Kepanjen. This is evidenced by the value of $\mathrm{t}>\mathrm{t}$ tablewith $\alpha=0.05$. The results support previous research conducted by La Siteni (2014/2015). From the research results concluded that school leadership have a significant effect on student achievement indicated by a correlation coefficient of 0.68 with a significant level of correlation and $\mathrm{KP}=46 \%$. This matching is also expressed by Nunu Nuchiyah (2004/2005) which states that the school leadership have a significant effect on student achievement with the correlation coefficient of 0.68 with a significant level of correlation and KP = $46 \%$. By creating an effective pemebelajaran process is one of the main factors of school leadership in SMP Negeri 1 Kepanjen. Skills principals in carrying out his duties as a leader greatly assist students in the learning process especially specialized in student learning achievement. This is shown by the principal so that the effect of leadership on student achievement at SMP Negeri 1 Kepanjen. By looking at the results of previous studies, we can conclude that the results of this study support previous research to strengthen the research results.

\subsubsection{Influence of the Teacher Performance Achievement}

Based on the results of research and data analysis, the result for the performance of teachers to teach a significant effect on student achievement at SMP Negeri 1 Kepanjen. This is evidenced by the value of $t>t$ table with $\alpha=0.05$ and an influential variable dominant because it has the largest coefficient value, which means that the better the performance of teachers to teach the higher the students' learning achievements obtained, and vice versa. The results support previous research conducted by La Siteni (2014/2015) which concluded that the performance of teachers to teach a significant effect on student achievement with a correlation coefficient of 0.73 . By (KP) by 53\%. Nunu Nuchiyah (2004/2005) in his study also concluded that the performance of teachers to teach a significant effect on student achievement, This is evidenced by the valuecorrelation coefficient of 0.73 and (KP) by 53\%. By looking at the results of previous studies it can be concluded that the results of this study support previous research to strengthen the research results.

\subsubsection{Influence on Learning Achievement Learning Facilities}

Based on the results of research and analysis on the data, the teaching facilities had no significant effect on student achievement SMP Negeri 1 Kepanjen. This is evidenced by the value of $t<t$ table with $\alpha=0: 05$. The results of this study do not support the results of previous research conducted by Prastiwi Yulianti (2014) which concluded that the learning facilities have a significant effect on student achievement amounted to $24.5 \%$. The learning facilities the direct and indirect impact on learning outcomes. The total effect of learning facilities to the learning outcomes through learning motivation is $34.2 \%$. The journal can be concluded from the complete absence of learning facilities that are owned and use of the facility itself will determine the quality of the learning process, because the learning process will take place effectively if supported means good. Nur Riwayati (2014/2015) in his study also concluded that there is a learning facility effect on student achievement with a partial contribution rate of $6.002 \%$. So the better the learning facility then learning achievement will be good too, and vice versa increasingly ugly learning facility then learning achievements are also increasingly ugly. One of the reasons why learning facilities no significant effect on learning achievement is due to the learning facilities in SMP Negeri 1 Kepanjen inadequate, such as equipment library less support, provision of instructional media in teaching and learning such as graphics, charts and LCD are minimal, props are minimal and completeness of lab facilities were minimal. This is in line with the results of the study with the lowest frequency in 
the variable learning facility is the indicator of the library. Learning resources in the library will be very helpful for the students to be more active search for learning resources through books, newspapers and other sources that can add to the source of knowledge. From these two previous studies that have been described above, it can be concluded that this study does not support previous research to strengthen the research results. Learning resources in the library will be very helpful for the students to be more active search for learning resources through books, newspapers and other sources that can add to the source of knowledge. From these two previous studies that have been described above, it can be concluded that this study does not support previous research to strengthen the research results. Learning resources in the library will be very helpful for the students to be more active search for learning resources through books, newspapers and other sources that can add to the source of knowledge. From these two previous studies that have been described above, it can be concluded that this study does not support previous research to strengthen the research results.

\subsubsection{Implications of Research Results}

Based on the results of research and discussion as described above, there are several implications of these results are related or linked to student achievement. The implications of these results, among others:

1) The actual condition of school leadership capable of giving rise to student achievement, so that the impact on student achievement is also very good. By creating an effective learning process is one of the main factors of school leadership in SMP Negeri 1 Kepanjen. Skills principals in carrying out his duties as a leader greatly assist students in the learning process especially specialized in student learning achievement. This is shown by the principal so that the leadership effect on learning achievement at SMP Negeri 1 Kepanjen In this case.

2) The actual condition of teacher performance has been good, so it can give rise to student achievement. Nevertheless, there is still one aspect of teachers' performance that need to be repaired again, the ability of the implementation of learning using media and learning resources. Media is anything that can be used to distribute messages (teaching materials), stimulate the mind, feelings, concerns, and the ability of students, so as to facilitate the learning process. In fact in the field of teachers have not fully utilize existing media such as globes, maps, pictures and so on, or designing the media for the sake of learning such as creating media photographs, films, computer-based learning, and so on. Apart from the existing deficiencies,

3) The actual condition of school facilities not good enough or not enough, so it can not influence on student achievement. It seems obvious at various facilities, such as libraries that are less supportive equipment, props are minimal and completeness of lab facilities were minimal. Because, basically, learning resources in the library will be very helpful for the students to be more active search for learning resources through books, newspapers and other sources that can add to the source of knowledge. Shortage of learning facilities and utilization of ineffective and inefficient to increase the active participation of learners in the learning process so that the learning achievement will not be increased. Usually the active role of learners is because learners interested and interests with ongoing learning materials using existing learning facilities. By looking at the shortcomings of existing facilities in SMP Negeri 1 Kepanjen, then the learning facility has no effect on student achievement. In this case, heads of departments, heads of schools should Preparing various adequate learning facilities in the learning process so that their achievements have also increased.

\section{CONCLUSIONS AND SUGGESTIONS}

\subsection{Conclusion}

Based on the results of research and discussion conducted it can be concluded as follows:

1) Descriptive analysis showed that indicators of school leadership (X1) gained an average of 4.11. This indicates that respondents tend to agree that school leadership is able to contribute to student achievement. The average indicator of the performance of teachers (X2) of 4.3. This indicates that respondents tend to strongly agree that the performance of the teacher is able to contribute to student achievement. The average indicator of learning facilities (X3) of 4.39. This indicates that respondents tend to agree that learning facility capable of contributing to student achievement.

2) From the results of hypothesis testing showed that the leadership of the principal, the performance of teachers and learning facilities simultaneously significant effect on student achievement at SMP Negeri 1 Kepanjen.

3) From the hypothesis testing results show that variables learning facilities partially no significant effect on student achievement, while the variable of school leadership and teacher performance variable partially significant effect on student achievement at SMP Negeri 1 Kepanjen.

4) From these results, the researchers found that teachers' teaching performance variables dominant influence on student achievement. A good teacher performance in carrying out its duties and functions are needed in education, especially in improving student achievement. This suggests that the main thing to consider in improving student achievement is the extent to which the performance of teachers contribute fully in learning activities. 


\subsection{Suggestions}

In connection with the matters described above, it can be given suggestions as follows:

1) In order for student achievement SMP Negeri 1 Kepanjen may continue to rise, the indicator implement effective management of learning resources in the variable of school leadership needs to be increased again. This is in line with the results of the study with the lowest frequency in the variable of school leadership are the indicators of implementing effective management of learning resources.

2) In order for student achievement SMP Negeri 1 Kepanjen may continue to rise, the indicator variable libraries on learning facilities need to be considered again. This is in line with the results of the study with the lowest frekueni on variable learning facility is the indicator of the library. Learning resources in the library will be very helpful for the students to be more active search for learning resources through books, newspapers and other sources that can add to the source of knowledge.

3) In order for student achievement SMP Negeri 1 Kepanjen may continue to rise, the indicator of the implementation of learning activities on teacher performance variables need to be considered by the leadership. This is in line with the results of the study with the lowest frekueni on teachers' performance variable is the indicator of the implementation of learning activities.

\section{REFERENCES}

1. Supriadi, D. 2001. Mengangkat Citra dan Martabat Guru. Yogyakarta: Adicita Karya Nusa.

2. Depdiknas.2003. Undang-undang RI No.20 tahun 2003.tentang sistem pendidikan nasional.

3. Bafadal. 2003. Peningkatan Profesionalisme Guru Sekolah Dasar dalam Kerangka Manajemen Peningkatan Mutu Berbasis Sekolah. Jakarta Bumi Aksara.

4. Tatang M. Amiri, dkk. 2011. Manajemen Pendidikan. Yogyakarta: UNY Press.

5. Slameto. 2010. Belajar dan faktor-faktor yang mempengaruhinya. Jakarta: PT Rineka Cipta.

6. Tirtonegoro. S. 2001. Penelitian Hasil Belajar Mengajar. Surabaya : Usaha Nasional

7. Thoha. M. 2008. Perilaku Organisasi : Konsep Dasar dan Aplikasinya. Jakarta : Raja Grafindo Persada.

8. Mulyasa. E. 2003. Managemen Berbasis Sekolah. Bandung: Penerbit PT Remaja Rosdakarya.

9. Wahjosumidjo. 2007. Kepemimpinan Kepala Sekolah, Tinjauan Teoritik dan Permsasalahannya. Jakarta: Raja Grafindo Persada.

10. Handoko. R. 2004. Organisasi Perusahaan Teori Struktur dan Perilaku. BPFE, Yogyakarta.

11. Mangkunegara. A.P. 2005. Manajemen Sumber daya Manusia Perusahaan. Bandung: PT Remaja Rosdakarya

11. Sujak. A. 2010. Kepemimpinan Manajemen, Eksistensinya Dalam Perilaku Organisasi, Rajawali, Jakarta.

12. Handoko. T.H. 2001. Manajemen Personalia dan Sumber Daya Manusia. Yogyakarta: BPFE Yogyakarta.

13. Daryanto, M. 2006. Administrasi Pendidkan. Jakarta: PT Rineka Cipta.

14. Djamarah, Bahri.S dan Zain.A. 2010. Strategi Belajar Mengajar. Jakarta: Rineka Cipta.

15. Daryanto dan Farind. M. 2013. Konsep Dasar Manajemen Pendidikan di Sekolah. Yogyakarta: Grava Media

16. Schneider, A.A. 2008. Personal Adjustment and Mental Health. New York: Holtt. Renehart and Winston Inc.

17. Sanusi. A. 2011. Metode Penelitian Bisnis. Salemba Empat, Jakarta

18. Arikunto. S. 2002. Prosedur Penelitian Suatu Pendekatan Praktek. Jakarta. PT. Rineka Cipta.

19. Arikunto. S. 2013. Prosedur Penelitian: Suatu Pendekatan Praktik. Jakarta: Rineka Cipta.

20. Sugiyono. 2011. Metode Penelitian Kuantitatif, Kualitatif dan R\&D. Bandung: Afabeta 